\title{
Nanoparticle strategies for cancer therapeutics: Nucleic acids, polyamines, bovine serum amine oxidase and iron oxide nanoparticles (Review)
}

\author{
ENZO AGOSTINELLI ${ }^{1}$, FABIO VIANELLO $^{2}$, GIUSEPPE MAGLIULO $^{3}$, THRESIA THOMAS $^{4}$ and T.J. THOMAS ${ }^{5}$ \\ ${ }^{1}$ Istituto Pasteur-Fondazione Cenci Bolognetti Department of Biochemical Sciences 'A. Rossi Fanelli', Sapienza \\ University of Rome and CNR, Institute of Biology and Molecular Pathology, 00185 Rome, Italy; ${ }^{2}$ Department of \\ Comparative Biomedicine and Food Science, University of Padua, 35020 Legnaro, Italy and Regional Centre \\ of Advanced Technologies and Materials, Department of Physical Chemistry, Palacky University in Olomouc, \\ Olomouc 77146, Czech Republic; ${ }^{3}$ Department Organi di Senso, Sapienza University of Rome, 00185 Rome, \\ Italy; ${ }^{4}$ Formerly Department of Environmental and Occupational Medicine, Rutgers Robert Wood Johnson Medical \\ School, Rutgers the State University of New Jersey, Piscataway, NJ 08854; ${ }^{5}$ Department of Medicine, Rutgers Robert \\ Wood Johnson Medical School, Rutgers the State University of New Jersey, New Brunswick, NJ 08901, USA
}

Received July 31, 2014; Accepted September 1, 2014

DOI: $10.3892 /$ ijo.2014.2706

\begin{abstract}
Nanotechnology for cancer gene therapy is an emerging field. Nucleic acids, polyamine analogues and cytotoxic products of polyamine oxidation, generated in situ by an enzyme-catalyzed reaction, can be developed for nanotechnology-based cancer therapeutics with reduced systemic toxicity and improved therapeutic efficacy. Nucleic acid-based gene therapy approaches depend on the compac-
\end{abstract}

Correspondence to: Professor Enzo Agostinelli, Department of Biochemical Sciences 'A. Rossi Fanelli', Sapienza University of Rome, Piazzale A. Moro 5, 00185 Rome, Italy

E-mail: enzo.agostinelli@uniroma1.it

Abbreviations: MDR, multidrug resistance; WT, wild-type; BSAO, bovine serum amine oxidase; SEM, scanning electron microscopy; TEM, transmission electron microscopy; P-gp, P-glycoprotein; ALDH, aldehyde dehydrogenase; ROS, reactive oxygen species; PEG, poly(ethylene glycol); ODC, ornithine decarboxylase; AOs, amine oxidases; PAOs, polyamine oxidases; ADR, doxorubicin resistant cells; FAD, flavin adenine dinucleotide; METC, mitochondrial electron transport chain; TPQ, 2,4,5-trihydroxyphenylalaninequinone; LTQ, lysine tyrosylquinone; MAO, mono amine oxidase; APAO, $\mathrm{N}^{1}$-acetylpolyamine oxidase; $P A O h 1$, first human polyamine oxidase; $\mathrm{SMO}$, spermine oxidase; TNF $\alpha$, tumor-necrosis factor; CLIO, crosslinked iron oxide; IU, International Unit; MRI, magnetic resonance imaging; SAMNs, superparamagnetic maghemite nanoparticles; $\mathrm{NH}$, nanohydrogel; $\mathrm{HA}$, hyaluronic acid; $\mathrm{CH}$, cholesterol

Key words: polyamines, DNA nanoparticles, multidrug resistance, bovine serum amine oxidase, gene therapy, biomaterials, magnetic nanoparticles tion of DNA/RNA to nanoparticles and polyamine analogues are excellent agents for the condensation of nucleic acids to nanoparticles. Polyamines and amine oxidases are found in higher levels in tumours compared to that of normal tissues. Therefore, the metabolism of polyamines spermidine and spermine, and their diamine precursor, putrescine, can be targets for antineoplastic therapy since these naturally occurring alkylamines are essential for normal mammalian cell growth. Intracellular polyamine concentrations are maintained at a cell type-specific set point through the coordinated and highly regulated interplay between biosynthesis, transport, and catabolism. In particular, polyamine catabolism involves copper-containing amine oxidases. Several studies showed an important role of these enzymes in developmental and disease-related processes in animals through the control of polyamine homeostasis in response to normal cellular signals, drug treatment, and environmental and/or cellular stress. The production of toxic aldehydes and reactive oxygen species ( $\mathrm{ROS}$ ), $\mathrm{H}_{2} \mathrm{O}_{2}$ in particular, by these oxidases suggests a mechanism by which amine oxidases can be exploited as antineoplastic drug targets. The combination of bovine serum amine oxidase (BSAO) and polyamines prevents tumour growth, particularly well if the enzyme has been conjugated with a biocompatible hydrogel polymer. The findings described herein suggest that enzymatically formed cytotoxic agents activate stress signal transduction pathways, leading to apoptotic cell death. Consequently, superparamagnetic nanoparticles or other advanced nanosystem based on directed nucleic acid assemblies, polyamine-induced DNA condensation, and bovine serum amine oxidase may be proposed for futuristic anticancer therapy utilizing nucleic acids, polyamines and BSAO. BSAO based nanoparticles can be employed for the generation of cytotoxic polyamine metabolites. 


\section{Contents}

1. Introduction

2. Nucleic acid assemblies and their use as drug delivery vehicles

3. Polyamines and their role in DNA condensation to nanoparticles

4. Amine oxidases and their utilization in nanomedicine

5. Cell killing by polyamines and BSAO

6. Hyperthermia in combination with polyamine metabolites in therapeutic applications

7. Nanoparticle delivery of BSAO in cancer cells

8. Conclusions and future perspectives

\section{Introduction}

Nanotechnology, concerning particles and devices in the range of 1-100 nm dimension, provides new opportunities in cancer therapy. Nanoparticle based therapies have been shown to reduce systemic toxicities and improve therapeutic efficacy of drugs (1). Doxil (liposomal-polyethylene glycol doxorubicin), DanoXome (liposomal daunorubicin), Oncaspar (Polyethylene glycol-L-Asparaginase), and Abraxane (albumin-bound paclitaxel) are FDA approved therapeutic nanoparticles. There are many nanoparticle-based agents in clinical trials aimed at reducing the toxicity of chemotherapeutic drugs, such as paclitaxel, camptothecin, doxorubicin, and cisplatin (1-4). In addition, nanotechnology for cancer gene therapy is an emerging field (5). Non-viral vectors for nanoparticle-based gene therapeutics are expected to overcome limitations due to pathogenicity and immunogenicity of viral vectors. This review introduces advances in the research of novel nanoparticles based on directed nucleic acid assemblies and polyamineinduced DNA nanoparticles as well as bovine serum amine oxidase-based nanoparticles to overcome some of the problems associated with conventional anticancer therapy, including the limitations of treating drug resistant tumours.

\section{Nucleic acid assemblies and their use as drug delivery vehicles}

Nucleic acids are the fundamental molecules of life and the complementarity of base pairing allows them to direct information transfer and cellular functions. DNA helices are inherently nanoscale building blocks with a diameter of approximately $2 \mathrm{~nm}$, a helical repeat of $3.4 \mathrm{~nm}$ (10.5 base pairs) and a persistence length of approximately $50 \mathrm{~nm}$ (4). Inspired by the Holliday junction, a four-way junction intermediate observed during recombination (6), Seeman first proposed thermodynamically stable four-way junctions with sticky ends and built double cross-over and triple cross-over motifs (7). Two-dimensional lattice, and polyhedral DNA structures such as the cube, sixconnected network, pentagonal dodecahedron and truncated octahedron were also designed by Seeman and others $(8,9)$. The tile structures further helped to build double-double crossovers and 3-, 4-, 6-, 8-, and 12-helix DNA tile complexes (10-12). Nanogrids, nano ribbons, and nanotubes were created in this manner. Three point stars, six-point stars, and T-shaped junctions increased the versatility of nanostructures based on tile-based self-assembly (12-14). T-shaped structures can give rise to orthogonal co-ordinated ladders, lattices and polar coordinated wheels (14).

The design process in tile-based DNA engineering is tedious with the assembly requiring strictly balanced stoichiometry, and the structures are limited by the length of the synthetic oligonucleotides (4). 'DNA origami' is a more recent and versatile method, first developed by Rothemund (15). The term origami refers to the Japanese folk art of folding paper into a special shape $(9,15)$. In this method, one long strand of singlestranded DNA (7.3 kb bacteriophage M-13 DNA) is folded to produce the desired structure by the help of smaller (32 bp) staple strands. The small staple strands are complementary to at least two distinct segments of the long single stranded DNA. The long single stranded DNA and an excess of staple strands are heat-annealed to form the origami. The origami method is formulated to yield 2-dimensional and 3-dimensionl structures and use double stranded DNA. Other investigators $(16,17)$ reported the formation of multi-domain DNA origami by using origami four-way junctions. DNA origami can also be used as a template for patterns using streptavidin molecules or enhanced green fluorescent protein $(18,19)$. Hung et al $(20)$ reported the positioning of gold nanoparticles on lithographically confined DNA origamies. Development of a molecular robot consisting of a DNA walker that moves on top of an origami in a programmed path and collects specified cargo is another advancement in this field (21-23). Strategies have been developed to make 3D structures such as three, four and six sided prisms (24) icosahedrons (25), 3D DNA box with an openable lid (26), 3D DNA box origami (27) and a tetrahedron DNA container (28).

A new route to building three dimensional nanostructures has been opened by the development of DNA bricks analogous to the LEGO building model (29). The basic building block in the structures is a 32-nucleotide single-stranded DNA which contains four regions that can hybridize to four neighbouring DNA strands. To build 3D structures, DNA bricks resembling two-stud LEGO bricks are connected with $90^{\circ}$ left-handed turn, resulting in layers of bricks that are shifted $90^{\circ}$ relative to each other. Whereas LEGO structures are assembled by hand, brick by brick, the DNA structures form by self-assembly. Each DNA brick is encoded with an individual sequence that determines its position and allows the structure to assemble by hybridization of complementary strands. In a one-step procedure, a cuboid structure is formed in $\sim 72 \mathrm{~h}$. By creating empty boxes and open-cavity shapes, tunnels of varying width, depth, and geometry authors allude to many types of functional nanodevices including drug-delivery vehicles (29).

Several research groups have explored the possibility of using 3-dimensional nanocontainers as delivery vehicles. Erben et al (30) demonstrated the encapsulation of cytochrome $\mathrm{c}$ within a DNA tetrahedral cage, where the protein molecule is conjugated to the 5'-end of one of the DNA strands via a surface amine. The ability of a DNA origami nanocage to encapsulate Au nanoparticles with various sizes has also been demonstrated (31). Anderson et al (32) created a nanoscale box with a cavity large enough to contain a ribosome and a controllable lid. Douglas and collaborators (33) engineered a DNA capsule fitted with aptamers that can be loaded with molecular cargo and unloaded upon binding to a desired target cell. DNA 
icosahedron structures were also designed and constructed as smart drug delivery vehicles (34). Taken together, these studies provide the initial proof-of-principle for developing and using DNA nanocontainers for drug delivery.

\section{Polyamines and their role in DNA condensation to nano- particles}

Polyamines are polycationic biogenic amines required for both eukaryotic and prokaryotic cell growth and differentiation $(35,36)$. The natural polyamines (putrescine $\left[\mathrm{NH}_{2}\left(\mathrm{CH}_{2}\right)_{4} \mathrm{NH}_{2}\right]$, spermidine $\left[\mathrm{NH}_{2}\left(\mathrm{CH}_{2}\right)_{4} \mathrm{NH}\left(\mathrm{CH}_{2}\right)_{3} \mathrm{NH}_{2}\right]$ and spermine $\left.\left[\mathrm{NH}_{2}\left(\mathrm{CH}_{2}\right)_{3} \mathrm{NH}\left(\mathrm{CH}_{2}\right)_{4} \mathrm{NH}\left(\mathrm{CH}_{2}\right)_{3} \mathrm{NH}_{2}\right]\right)$ are formed from the decarboxylation products of ornithine and S-adenosyl-methionine in nearly all eukaryotic cells. In normal cells, polyamine concentrations are highly regulated by the action of biosynthetic and catabolising enzymes, such as ornithine decarboxylase (ODC) and spermidine/spermine acetyl transferase; however, polyamine levels are elevated in cancer cells (36). Motives for these increased levels include enhanced putrescine synthesis from ornithine by ODC, the rate-limiting enzyme, and an increased uptake of polyamines (37). However, in situations of over-accumulation or depletion of intracellular polyamine pools, cell death can occur $(38,39)$. Polyamines attract interest because of their multiple functions in cell biology, including cell cycle regulation, gene expression and signal transduction (40-43). The primary role of polyamines in regulating cell proliferation and cell death have prompted scientists to investigate the role of these compounds in mitochondria, multifunctional organelles participating in a range of cellular processes, such as energy production, proliferation, senescence and death (44). Mitochondria apparently lack a polyamine biosynthetic pathway, nevertheless substantial quantities of spermine and spermidine have been detected in the mitochondrial matrix and a specific mitochondrial polyamine transporter has been described (45).

In addition to their biological and gene regulatory roles, polyamines provoke the condensation of DNA on nanoparticles $(46,47)$. Condensation is an essential process for the packaging of DNA in cells. Hence, the mechanism of DNA condensation by polyamines and other multivalent cations has been an active area of research for the past forty years (48). This phenomenon has acquired further importance because condensed DNA can be transported into cells more efficiently than uncondensed DNA (47). Polycations such as polyethyleneimine, polylysine and cationic lipids have been used as DNA delivery agents in cells. These cations cause localized bending or distortion of DNA at a critical extent of charge neutralization, facilitating the formation of rods and toroid-like structures (49). Carlstedt et al (50) suggested that the association of DNA with polycations or surfactants might be manifested as compaction, a conformational change of single DNA chain from an extended coil to a compact globule or macroscopic phase separation, depending on the conditions. Although the general term condensation also covers compaction, condensation generally involves multiple DNA molecules. Beyond DNA condensation, an increased concentration of spermine on DNA result in phase separation. A miscibility gap has been found and the lower boundary of the phase separation region occurred at a spermine:DNA charge ratio close to unity (51).
With a large excess of spermine at charge ratios $>120$, clear solutions are formed beyond miscibility gap. Other studies also showed similar miscibility gaps in DNA mixtures with surfactants or cyclodextrins at much lower charge ratios than spermine (50). The ability of PEI, poly-L-lysine, surfactants, and cyclodextrins to condense DNA and the hydrodynamic properties of DNA nanoparticles produced by these agents have been characterized $(52,53)$. Structural specificity effects have been demonstrated in polyamine-mediated DNA condensation and oligonucleotide uptake in cells $(54,55)$. Polyamines and oligonucleotides also exert a synergistic inhibition of the transcription of targeted genes (55).

\section{Amine oxidases and their utilization in nanomedicine}

Polyamines are substrates for a large class of enzymes, the amine oxidases (AOs), including spermine oxidase and polyamine oxidases (PAOs). AOs regulate the level of polyamines in the cell. For example, PAOs are involved in polyamine homeostasis, while the other oxidases are important for the terminal catabolism of polyamines, i.e. they catalyse the formation of metabolites, like ammonia and amino acids, which are excreted through the kidney (56). These enzymes operate by abstracting two electrons from primary amines and transferring them to molecular oxygen to produce the corresponding aldehyde, ammonia and hydrogen peroxide, according to the following equation:

$$
\text { R- }-\mathrm{CH}_{2}-\mathrm{NH}_{3}{ }^{+}+\mathrm{O}_{2}+\mathrm{H}_{2} \mathrm{O} \stackrel{\text { Amine Oxidase }}{\longrightarrow} \mathrm{R}-\mathrm{CHO}+\mathrm{NH}_{4}{ }^{+}+\mathrm{H}_{2} \mathrm{O}_{2}
$$

The superfamily of AOs represents an important class of enzymes, which are present in numerous living systems. These enzymes differ with respect to their molecular architecture, catalytic mechanisms, and patterns of substrate specificity, inhibitor sensitivity, and subcellular localizations (57). In the most common classification, these enzymes (amine: oxygen oxidoreductases, AOs, E.C. 1.4.3.4.) are divided into two classes, based on the chemical nature of the cofactors involved (58). The first class is characterized by the presence of flavin adenine dinucleotide (FAD; FAD-AOs) and is ubiquitous in most mammalian species, whereas PAOs are found principally in vertebrates and plants (59). The second class consists of enzymes having a tightly bound $\mathrm{Cu}^{2+}$ ion and a carbonyl-type group identified as either a 6-hydroxydopa quinone (2,4,5-trihydroxyphenylalaninequinone, TPQ) or a lysine tyrosylquinone (LTQ) at their active site. TPQ is easily detected due to its pink absorption in the visible region, approximately at $480 \mathrm{~nm}$ (60). FAD- and $\mathrm{Cu}^{2+} / \mathrm{TPQ}$-amine oxidases have been isolated and characterized from numerous organisms, ranging from microorganisms, plants and mammals. FAD-AOs are mainly intracellular enzymes, often associated with the outer mitochondrial membrane $(61,62)$, whereas $\mathrm{CuAOs}$ are either intra- or extra-cellular enzymatic proteins, or in some cases integral plasma membrane proteins (63-65).

A peroxisomal FAD-dependent enzyme, $\mathrm{N}^{1}$-acetylpolyamine oxidase (APAO), is a constitutively expressed enzyme that catalyses the cleavage of acetylated polyamines to produce spermidine (from spermine) or putrescine (from spermidine), 3-aceto-aminopropanal and $\mathrm{H}_{2} \mathrm{O}_{2}$. Wang et al (66) identified 
Table I. Clonogenic assay: dose response.

$\%$ Cell survival in cell lines

\begin{tabular}{cccrr}
\cline { 2 - 4 } Spermine $(\mu \mathrm{M})$ & LoVo WT & LoVo DX & M14 WT & M14 ADR \\
\hline 0 & $100.0 \pm 0.0$ & $100.0 \pm 0.0$ & $100.0 \pm 0.0$ & $100.0 \pm 0.0$ \\
3 & $84.0 \pm 5.09$ & $29.0 \pm 4.30$ & $77.1 \pm 4.5$ & $68.8 \pm 3.53$ \\
6 & $45.0 \pm 6.70$ & $7.5 \pm 1.30$ & $37.1 \pm 1.5$ & $18.8 \pm 0.98$ \\
12 & $1.7 \pm 0.62$ & $0.2 \pm 0.02$ & $14.6 \pm 3.1$ & $10.4 \pm 0.56$ \\
15 & $0.4 \pm 0.02$ & $0.1 \pm 0.09$ & $5.6 \pm 0.1$ & $2.6 \pm 0.18$ \\
\hline
\end{tabular}

Effect of exogenous spermine concentration $(0-15 \mu \mathrm{M})$ on percentage cell survival in LoVo WT, LoVo DX, M14 WT and M14 ADR in the presence of BSAO $\left(6.54 \times 10^{-3} \mathrm{U} / \mathrm{ml}\right)$, during $60 \mathrm{~min}$ of incubation at $37^{\circ} \mathrm{C}$. Means and SDs are shown for two to five estimations from four to six experiments.

$\mathrm{NH}_{2}\left(\mathrm{CH}_{2}\right)_{3} \mathrm{NH}\left(\mathrm{CH}_{2}\right)_{4} \mathrm{NH}\left(\mathrm{CH}_{2}\right)_{3} \mathrm{NH}_{2}+2 \mathrm{O}_{2}+2 \mathrm{H}_{2} \mathrm{O}$

(Spermine)

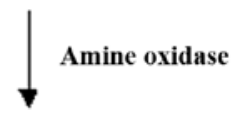

$\mathrm{CHO}\left(\mathrm{CH}_{2}\right)_{2} \mathrm{NH}\left(\mathrm{CH}_{2}\right)_{4} \mathrm{NH}\left(\mathrm{CH}_{2}\right)_{2} \mathrm{CHO}+2 \mathrm{NH}_{3}+2 \mathrm{H}_{2} \mathrm{O}_{2}$

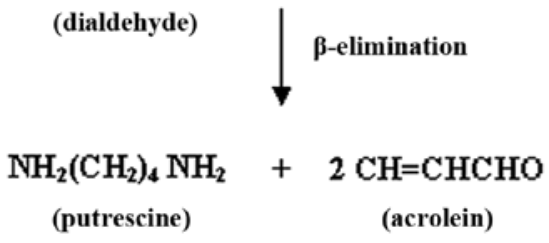

Figure 1. Reaction scheme for spermine oxidation in the presence of BSAO.

a gene (PAOh1) for an enzyme capable of oxidizing unsubstituted spermine. Vujcic et al (67) subsequently confirmed that this new gene/enzyme was also involved in the polyamine catabolic pathway. The new enzyme, named SMO is a highly inducible FAD-dependent enzyme that oxidizes spermine to produce spermidine, 3-aminopropanal and $\mathrm{H}_{2} \mathrm{O}_{2}$. Subsequent studies indicated that SMO might represent a target for chemoprevention (68). In fact, using tumor-necrosis factor ( $\mathrm{TNF} \alpha$ ), a pleiotropic inflammatory cytokine, it was shown that this general mediator of inflammation was able to stimulate SMO activity, resulting in a potential damage induced by reactive aldehydes and ROS. The aldehyde, 3-aminopropanal, and $\mathrm{H}_{2} \mathrm{O}_{2}$, once converted into the highly reactive hydroxyl radical (HO') through Fenton-like-catalysis, can damage RNA, DNA, membranes and proteins. A severe damage to DNA, by both enzymatic oxidation products, can lead to mutagenic changes necessary for the development and progression of multiple epithelial cancers. In addition, $\mathrm{H}_{2} \mathrm{O}_{2}$ formed by polyamine catabolism might play a role as a signaling molecule $(69,70)$.

\section{Cell killing by polyamines and BSAO}

Attempts to exploit polyamine metabolizing enzymes as therapeutic targets, as well as to utilise the polyamine backbone as pharmacophore for the design of anticancer drugs have been investigated and reviewed $(71,72)$. Our findings showed the possibility of using purified BSAO in the presence of exogenous spermine or endogenous polyamines to induce cytotoxicity (73). The mechanism of cell death induced by BSAO and spermine, in the extracellular environment was examined on human colon adenocarcinoma and melanoma cell lines, either drug-sensitive or multidrug resistant (MDR) $(74,75)$. The oxidation products of polyamines, $\mathrm{H}_{2} \mathrm{O}_{2}$ and aldehyde(s), have been implicated in programmed cell death, induction of cytotoxicity and inhibition of cell division (76,77). Cytotoxic metabolites of spermine formed in situ by an enzyme-catalyzed reaction might be useful for the destruction of tumours (Fig. 1). An important distinction between normal and tumour cells is related to polyamine content and metabolism; in general polyamine concentrations are high in rapidly growing tissues such as tumours (78). However, AO activity has a contrasting effect on cancer cells. On the one hand it inhibits cell growth and induces cell death by necrosis (79) and/or apoptosis $(74,80)$; on the other hand, AO activity has been correlated with cancer progression particularly when it is enhanced. Therefore, the involvement of AOs in cancer is associated with two different aspects: the direct regulation of the level of biogenic amines in cells and the formation of cytotoxic catabolites, i.e. $\mathrm{H}_{2} \mathrm{O}_{2}$ and aldehydes (74,79). Recently, several aspects of the role of AOs in cancer have been taken deeply into consideration by Toninello and collaborators (81).

The cytotoxicity induced by BSAO in the presence of exogenous spermine was evaluated in both colon adenocarcinoma LoVo WT and LoVo DX cell lines as a function of spermine concentration as well as of exposure time, at $37^{\circ} \mathrm{C}$. Table I shows the percentage of cell survival as a function of exogenous spermine concentration up to $15 \mu \mathrm{M}$ in the presence of BSAO, after $60 \mathrm{~min}$ of incubation. Multidrug-resistant (MDR) cells are more affected by treatment with spermine compared to their drug-sensitive counterparts. For instance, at $6 \mu \mathrm{M}$ spermine concentration, the survival of LoVo WT cells was approx. $45 \%$, while only a very low percentage of $7.5 \%$ in LoVo DX cells maintained their viability. To evaluate the contribution of $\mathrm{H}_{2} \mathrm{O}_{2}$ to cytotoxicity, with respect to other enzymatic oxidation products, experiments were carried out in the presence of catalase. Catalase is a hydrogen peroxide-scavenging enzyme which converts $\mathrm{H}_{2} \mathrm{O}_{2}$ into water and oxygen. There was a remarkable $\sim 80 \%$ reduction of cytotoxicity in both cell lines, apparently due to the clearance of $\mathrm{H}_{2} \mathrm{O}_{2}$ by catalase. However, this result shows that $\mathrm{H}_{2} \mathrm{O}_{2}$ is 
Table II. Clonogenic assay: time course.

$\%$ Cell survival in cell lines

\begin{tabular}{lcccc}
\cline { 2 - 4 } Time (min) & LoVo WT (1) & LoVo DX (2) & LoVo WT (3) & LoVo DX (4) \\
\hline 0 & $100.0 \pm 0.0$ & $100.0 \pm 0.0$ & $100.0 \pm 0.0$ & $100.0 \pm 0.0$ \\
5 & $76.0 \pm 12.2$ & $45.0 \pm 3.8$ & $104.0 \pm 7.5$ & $106.0 \pm 11.3$ \\
10 & $53.0 \pm 10.4$ & $27.0 \pm 2.4$ & $102.0 \pm 18.3$ & $98.2 \pm 8.1$ \\
15 & $43.0 \pm 3.9$ & $24.7 \pm 2.1$ & $99.2 \pm 2.4$ & $98.0 \pm 16.5$ \\
20 & $40.2 \pm 6.8$ & $21.0 \pm 4.9$ & $97.0 \pm 3.7$ & $97.0 \pm 7.9$ \\
30 & $31.2 \pm 5.2$ & $13.7 \pm 8.1$ & $97.3 \pm 5.1$ & $96.0 \pm 8.6$ \\
40 & $20.2 \pm 3.3$ & $8.9 \pm 1.6$ & $96.8 \pm 2.3$ & $95.3 \pm 12.9$ \\
60 & $18.4 \pm 1.5$ & $4.8 \pm 1.4$ & $96.0 \pm 6.4$ & $94.0 \pm 2.8$ \\
\hline
\end{tabular}

Effect of catalase and ALDH on cytotoxicity induced by BSAO in the presence of spermine. LoVo WT and LoVo DX cells were incubated at $37^{\circ} \mathrm{C}$, up to $60 \mathrm{~min}$, with BSAO $\left(6.54 \times 10^{-3} \mathrm{U} / \mathrm{ml}\right)$ and exogenous spermine $12 \mu \mathrm{M}$, in absence of inhibitors (columns 1 and 2$)$, or with catalase $(240 \mathrm{U} / \mathrm{ml})$ and ALDH $(0.4 \mathrm{U} / \mathrm{ml})$ (columns 3 and 4). Means and SDs are shown for two to five estimations from four to six experiments.
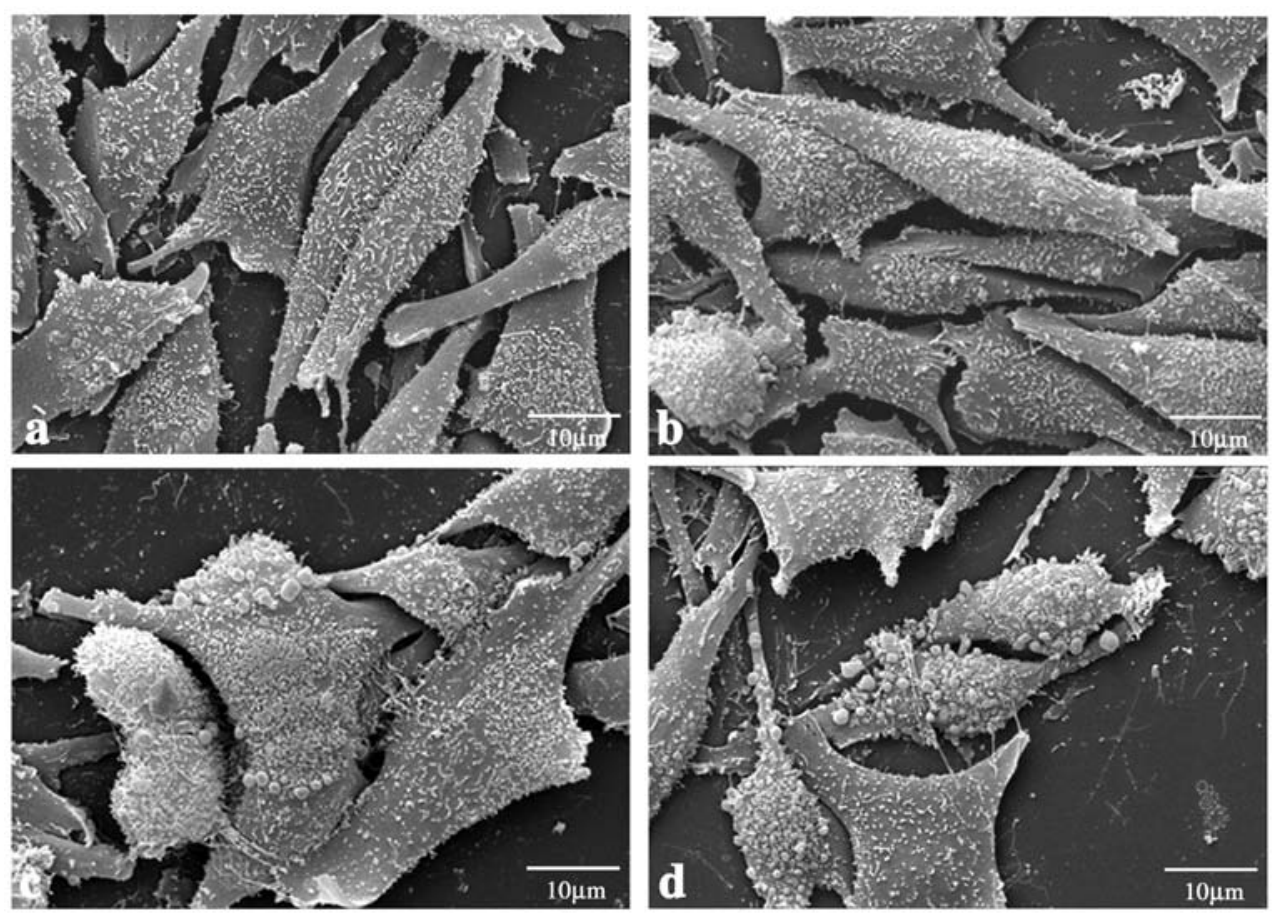

Figure 2. Effect of exposure to BSAO and spermine on the morphology of M14 WT and M14 ADR cells (scanning electron micrographs). (a) Untreated M14 WT cells. (b) Untreated M14 ADR cells. (c) M14 WT cells exposed for $60 \mathrm{~min}$ to $6.5 \times 10^{-3} \mathrm{IU} / \mathrm{ml} \mathrm{BSAO}$ and $6 \mu \mathrm{M}$ spermine at $37^{\circ} \mathrm{C}$. (d) M14 ADR cells, same treatment as in (c). Bars: $10 \mu \mathrm{m}$. From Agostinelli et al (74).

not the exclusive toxic agent and that other species might be involved, such as acrolein. In order to determine the contribution of aldehydes in provoking the cytotoxicity by BSAO/ spermine, catalase and NAD-dependent aldehyde dehydrogenase $(\mathrm{ALDH})$ were added to the incubation mixture. In these experimental conditions, cytotoxicity was completely inhibited throughout the $60 \mathrm{~min}$ of incubation (Table II). MDR human melanoma cells were more sensitive than the corresponding wild-type cells at all spermine concentrations tested. At the $6 \mu \mathrm{M}$ spermine concentration, survival of M14 WT cells was $37.1 \%$, while only $18.8 \%$ of the M14 ADR cells remained viable (Table I). As single agents, BSAO or spermine were not toxic to either cell line up to $15 \mu \mathrm{M}$ spermine.

The morphological and ultrastructural changes induced by treatment with $\mathrm{BSAO} /$ spermine were investigated by scanning (SEM) and transmission electron microscopy (TEM) to gain insight into the mechanism(s) responsible for the higher cytotoxic effect in MDR cells compared to drug-sensitive cells. Fig. 2 shows electron microscopic images of control M14 WT (panel a) and M14 ADR (panel b) cells, respectively, grown at $37^{\circ} \mathrm{C}$. These cells have elongated or polygonal shape and their surface are covered by randomly disseminated microvilli. 

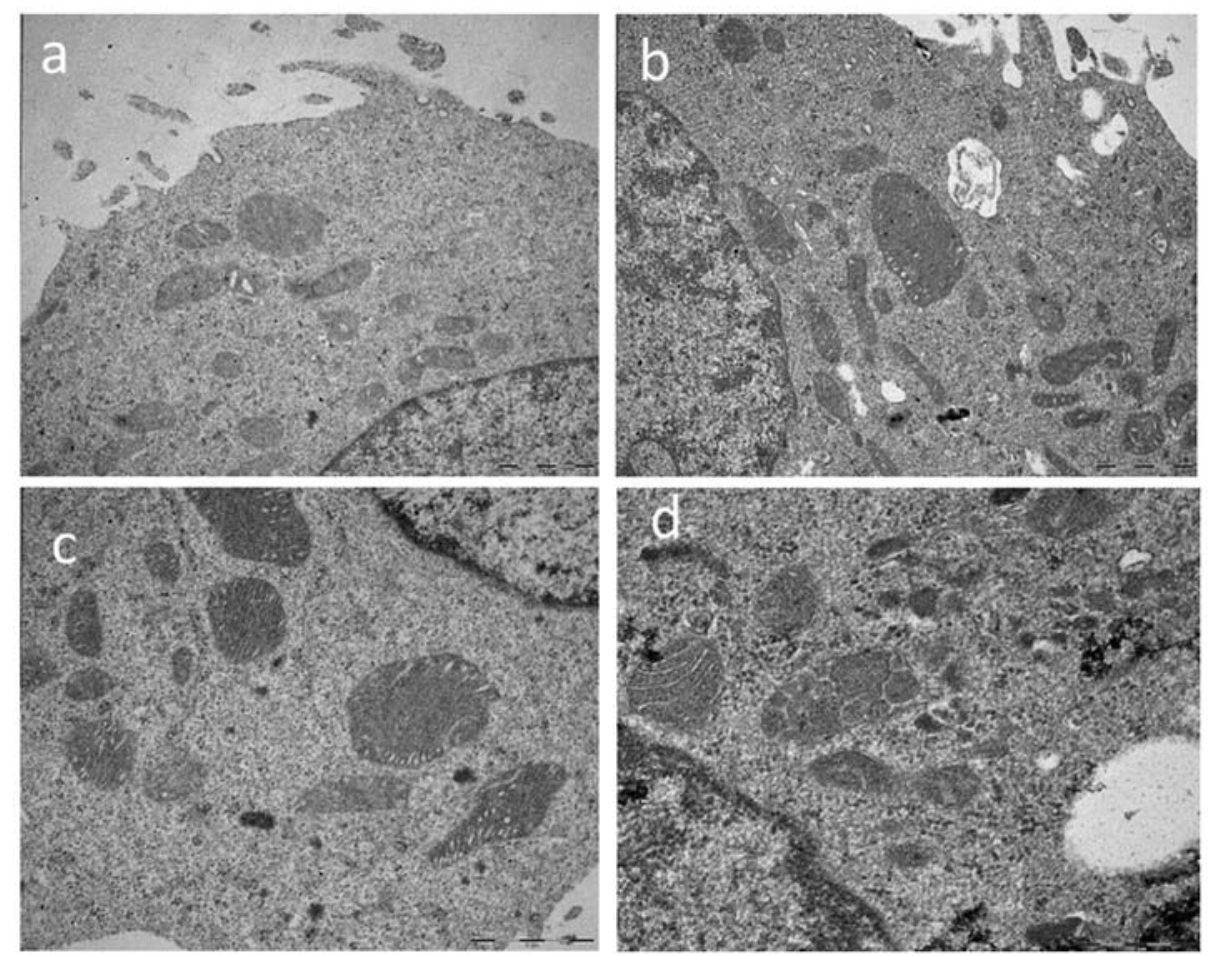

Figure 3. Ultrastructural features of mitochondria of M14 WT and M14 ADR cells (transmission electron micrographs). (a) Untreated M14 WT cells (b) Untreated M14 ADR cells. (c) M14 WT cells exposed for $60 \mathrm{~min}$ to $6.5 \times 10^{-3} \mathrm{IU} / \mathrm{ml} \mathrm{BSAO}$ and $6 \mu \mathrm{M}$ spermine at $37^{\circ} \mathrm{C}$. (d) M14 ADR cells, same treatment as in c. Bars: $0.5 \mu \mathrm{m}$. Panel b from Agostinelli et al (74).

After treatment with $\mathrm{BSAO} /$ spermine $(6 \mu \mathrm{M})$ at $37^{\circ} \mathrm{C}$, cells from both cell lines (images $\mathrm{c}$ and $\mathrm{d}$ ) appear less elongated than untreated control; some of them tended to become rounded with numerous blebs on their surface. These cells had a tendency to detach from the substrate. Both M14 WT and M14 ADR control cells, grown at $37^{\circ} \mathrm{C}$, showed a well-preserved ultrastructure when observed by TEM. The cytoplasm was characterized by the presence of numerous mitochondria with parallel cristae in a dense and uniform matrix (Fig. 3a and b). After exposure to $\mathrm{BSAO} /$ spermine $(6 \mu \mathrm{M})$ at $37^{\circ} \mathrm{C}$, M14 WT cells did not show any consistent aberration but some mitochondrial display dilated cristae (Fig. 3c). The alterations of mitochondria structure were much more evident in MDR cells; in particular, they showed a highly condensed matrix and vacuolised cristae (Fig. 3d). Similar morphological modifications and ultrastructural alterations were also observed in both LoVo colon adenocarcinoma cell lines, where MDR cells showed all the mitochondria visibly damaged.

Since mitochondria appear to play a pivotal role in determining the differential response between sensitive and drug-resistant cells, a flow cytometric study was carried out on LoVo cells to generate information on the mitochondrial activity. The results showed a basal hyperpolarized status of the mitochondria in control MDR LoVo cells. After the treatment with $\mathrm{BSAO} /$ spermine, the higher sensitivity to cytotoxic spermine derivatives observed in adenocarcinoma LoVo DX cells compared to their sensitive counterparts, has been therefore attributed to an earlier and higher mitochondrial membrane depolarisation. Moreover, a higher basal production of ROS was detected in MDR cells than that in drug-sensitive cells, suggesting an increased mitochondrial electron transport chain (METC) activity in MDR cells $(79,82)$.

\section{Hyperthermia in combination with polyamine meta- bolites in therapeutic applications}

Hyperthermia is an alternate to cytotoxic drug therapy. Conventional cancer chemotherapy encounters several difficulties, including poor selectivity of the cytotoxic drugs and the development of MDR in the course of drug treatment. The term "hyperthermia" is generally used to imply a treatment based on the generation of heat at the tumour site (83). This approach involves raising the temperature of local environment of a tumour, resulting in a change in the physiology of diseased cells and subsequent cell death. Hyperthermia can augment the efficacy of other therapeutic modalities, such as irradiation, chemotherapy, surgery, gene therapy and immunotherapy (84-86). During hyperthermia treatment, cells undergo heat stress in the temperature range of $41-46^{\circ} \mathrm{C}$, resulting in activation and/or initiation of several intra- and extra-cellular degradation mechanisms, such as protein denaturation and aggregation, and DNA cross linking. Permanent irreversible protein damage can occur with a single heat treatment, resulting in protein aggregation and/or inhibition of many cellular functions. Histological studies showed that the heating-induced tumour cell death was mostly achieved through necrosis rather than apoptosis (87). The challenge is to heat only the tumour mass without damaging healthy tissues.

Agostinelli and colleagues studied potential effects of both $\mathrm{H}_{2} \mathrm{O}_{2}$ and aldehyde(s) (produced by the $\mathrm{BSAO} /$ polyaminespermine enzymatic system) on the induction of cytotoxicity at $42^{\circ} \mathrm{C}$, rather than at $37^{\circ} \mathrm{C}(74,79,88)$. In these studies, the most important cytotoxic metabolite of spermine was $\mathrm{H}_{2} \mathrm{O}_{2}$. In fact, $\mathrm{H}_{2} \mathrm{O}_{2}$, either formed by the glucose oxidase reaction, or added as such to the cell suspension, was cytotoxic 
at a lower concentration than acrolein (89). In addition, $\mathrm{H}_{2} \mathrm{O}_{2}$ generated in situ from hypoxanthine by reaction with xanthine oxidase had anti-tumour effects in vivo (90). Both $\mathrm{H}_{2} \mathrm{O}_{2}$ and aldehyde(s), formed in the presence of BSAO and spermine $(6 \mu \mathrm{M})$ for $60 \mathrm{~min}$ of incubation at $42^{\circ} \mathrm{C}$, were responsible for cytotoxicity, since the addition of catalase alone did not result in complete protection of cells. These studies also showed that overexpression of P-glycoprotein (P-gp) in MDR cells did not confer resistance to the enzymatic oxidation products of spermine. This phenomenon might be caused by an earlier and higher mitochondrial membrane depolarization and a higher basal production of $\operatorname{ROS}(79,82)$.

Regional hyperthermia potentiates the cytotoxic action of many different anticancer drugs and has considerable potential in cancer treatment. Promising results are emerging from clinical studies involving hyperthermia combined with chemotherapy. A biological strategy to enhance the therapeutic effects of hyperthermia is to use heat in combination with pharmacological agents that show enhanced cytotoxicity at high temperatures. These thermosensitizer compounds, such as cysteamine and aminothiol N-(2-mercaptoethyl)-1,3propanediamine (WR-1065), are not toxic at $37^{\circ} \mathrm{C}$, but become inactivators of cellular function at elevated temperatures (91). Another group of drugs, all of which were considered to be heat sensitizers, are the naturally occurring polyamines putrescine, spermine and spermidine (92).

The enzymatic oxidation products of spermine behave in a manner similar to that of thermosensitizers $(93,94)$. Beneficial effects could therefore be achieved using localized heating to enhance the action of toxic products generated by $\mathrm{BSAO} /$ spermine within the tumour site, without increasing normal tissue damage. It was observed that the concentrations of spermine necessary to induce cytotoxicity were different in cell lines of various histotype $(74,79,95,96)$. An interesting result was that an inactive combination of spermine $(\leq 1 \mu \mathrm{M})$ and BSAO at $37^{\circ} \mathrm{C}$ became cytotoxic at $42^{\circ} \mathrm{C}$ for both human colon adenocarcinoma and melanoma cells, mimicking the action of thermosensitizers $(74,88)$. These findings suggested a marked enhancement of cytotoxicity on LoVo and M14 cells induced by heat, attributed to both the enzymatic oxidation products of spermine, $\mathrm{H}_{2} \mathrm{O}_{2}$ and aldehyde(s). Although still at an early stage, the in situ formation of toxic compounds or radicals by enzyme catalysed reactions is a promising start. For the slow release of toxic spermine metabolites into the tumour, the use of BSAO conjugated to biocompatible polymers is considered, as reported in Conclusions and Future Perspectives paragraph $(73,97)$.

\section{Nanoparticle delivery of BSAO in cancer cells}

A major impediment in advancing nanotechnology to the clinics is the inability of nanoparticles to undergo facile transport through the cell membrane. Several approaches have been attempted to circumvent this problem. We describe below some of the approaches used to transport BSAO in tumour cells.

Antitumoral effect in vitro and in vivo of native and immobilized BSAO on polyethylene glycol (PEG). In previous studies, $\mathrm{H}_{2} \mathrm{O}_{2}$ and aldehydes were produced outside the cells and subsequently entered inside the cells, producing cytotoxic effects. Catalytically liberated cytotoxic agents require only a few enzymatic units of the protein for toxin formation, and the cytotoxic reaction products are continuously formed over an extended period of time (57,98). Since endogenous polyamines are present at high concentrations in tumour cells and growing tissues, it is expected that toxic enzymatic oxidation products can be produced intracellularly by delivering BSAO directly into the cells, thereby achieving in situ killing of cells. Attempts were made to incorporate the enzyme into liposomal vesicles (99), and prepare amine oxidase-gold complexes that were bound and incorporated by hepatocytes (100). Thus, endogenous polyamines could be targeted and oxidized by the enzyme. In this context, attempts were made to produce immobilized BSAO to increase its plasmatic half-life and therapeutic efficacy and to decrease drug toxicity. The enzyme was conjugated to a bio-compatible non-immunogenic polymer, polyethylene glycol (PEG), and then immobilized into a hydrogel-type matrix (97). Hydrogels are hydrophilic macromolecular networks that possess high water content. This feature should allow a controlled delivery of the enzyme by crossing the cell membrane and then, also a controlled release of the enzyme in the intracellular environment to maintain a drug concentration at therapeutic levels. Therefore, the immobilized BSAO exhibited considerable advantages over the free enzyme. Both native and immobilized BSAO were then compared in vivo, in terms of their respective abilities to induce melanoma regression in mice by either apoptosis or necrosis. In fact, the growth of a mouse melanoma (B16-F0) was reduced by $70 \%$ after a single injection of the immobilized enzyme, in comparison with $32 \%$ inhibition after injection of the same amount of native BSAO. While the immobilized enzyme induced a high level (70\%) of apoptosis, non-apoptotic cell death prevailed in the case of the native enzyme (73). The difference of cell death ratio was attributed to the slow, gradual release of spermine enzymatic oxidation products from the hydrogel, i.e. the long-term exposure of the tumour to ROS and aldehydes, as compared with the shorter, though more rapid release of toxic metabolites by the native enzyme.

Iron oxide nanoparticles. Nanotechnological applications of iron oxides, namely maghemite $\left(\gamma-\mathrm{Fe}_{2} \mathrm{O}_{3}\right)$ and magnetite $\left(\mathrm{Fe}_{3} \mathrm{O}_{4}\right)$, have been intensely studied in different research areas, such as magnetic data storage $(101,102)$, pigment production (103), electrochemistry (104), biosensing $(105,106)$, drug delivery and protein purification (107). Cross-linked iron oxide (CLIO) (108), ultra-small superparamagnetic iron oxide (USPIO) (109), and mono-crystalline iron oxide nanoparticles (MIONs) (110) have been developed for diagnostic and therapeutic applications. Iron-oxide nanoparticles possess several superior properties, including magnetic properties (e.g. superparamagnetism, high values of saturation magnetization, easy control by small magnetic fields) and biochemical (e.g. non-toxicity, biodegradability, and biocompatibility) that justify their role in drug delivery. The ability of iron oxide nanoparticles to undergo cellular phagocytosis facilitates their use in contrast enhanced MRI beyond vascular and tissue morphology imaging (111), thereby enabling novel applications of iron oxide nanoparticles for MRI based diagnosis of liver diseases, cancer metastasis to lymph nodes, and in vivo tracking of implanted cells and grafts. Functionalized and 


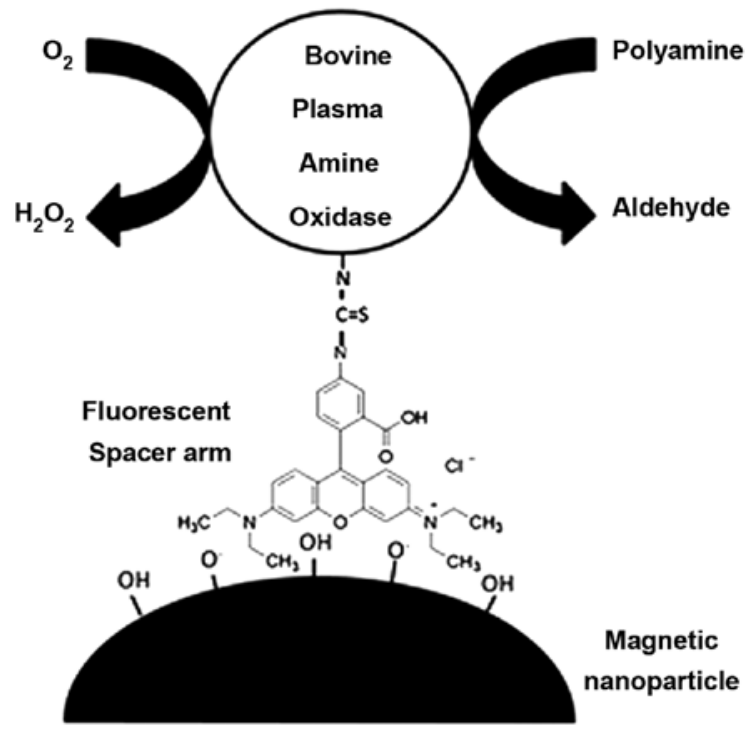

Figure 4. Schematic representation of fluorescent and magnetically drivable adduct comprising BSAO immobilized on the surface of specifically functionalized magnetic nanoparticles.

engineered magnetic nanoparticles have been developed to meet the increasing demand for non-invasive in vivo imaging of molecular and cellular activities, specific to a disease state. Several biomarkers, such as antibodies (32), aptamers (112), enzymes (113), peptide fragments (114) and polysaccharides (115) were used to achieve specificity and to reduce adverse side effects of iron oxide nanoparticles.

The possibility to convert dissipated magnetic energy into thermal energy led to the development and application of magnetic materials for hyperthermia treatment of cancer $(83,116)$. Magnetic nanoparticles used for hyperthermia are only few tens of nanometer in size and therefore, allows easy passage into several tumours whose pore sizes are in $380-780 \mathrm{~nm}$ range. It was also found that irradiation of magnetic nanoparticles with a radio-frequency (in the range $100 \mathrm{kHz}-1 \mathrm{MHz}$ ) led to an increase in media temperature. This phenomenon can be used to increase the temperature of cells and tissue, and can be used in conjunction with hyperthermia for therapeutic purpose.

The controlled release of drugs with spatiotemporal control is the key to meeting several challenges in drug delivery applications. Controlled release of drugs from nanoparticle based delivery systems, triggered by a number of external stimuli, has been extensively studied (117). Iron oxide nanoparticles have the ability to act as chemotherapeutic agents to release drugs in a controlled manner. The most important advantage of nanoparticle-drug adducts, once that they have been released inside the cell, resides on their retention within the cell at concentrations sufficient to inhibit cell growth and functions, providing sustained drug release and improvement of treatment efficacy. Moreover, the ability of short interfering RNA (siRNA) to silence specific genes inspired the use of siRNA as a therapeutic agent for a wide spectrum of disorders including cancer, infectious diseases, and metabolic disturbances (118). In order to optimize the delivery of siRNA and enhance the efficiency of the treatment, the preparation of magnetic nanoparticles for imaging and siRNA delivery specifically

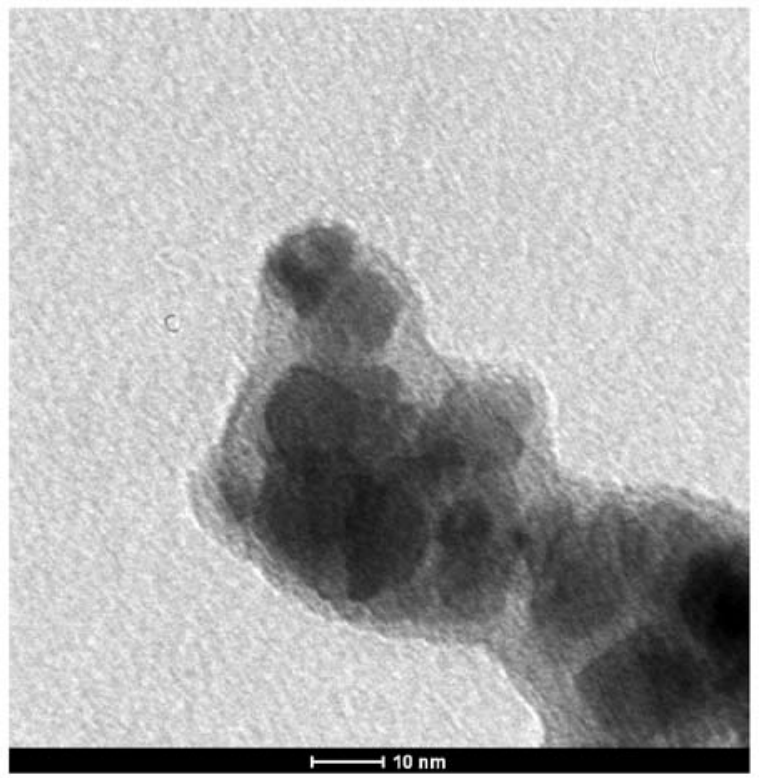

Figure 5. TEM image of maghemite nanoparticles derivatized with RITC and immobilized BSAO (SAMN@RITC-BSAO), as shown in Fig. 3. From Sinigaglia et al (122).

to cancer cells was proposed (119). Iron oxide nanoparticles may be combined with different active agents, which could be proposed for therapy and diagnosis (120), thereby realizing their potential as theranostic agents.

BSAO bound to nanosized magnetic nanoparticles. Recently, a novel synthetic procedure for nanostructured superparamagnetic material in the size range approximately $10 \mathrm{~nm}$, constituted of stoichiometric maghemite $\left(\gamma-\mathrm{Fe}_{2} \mathrm{O}_{3}\right)$, and showing peculiar surface chemical behavior, called SAMNs (surface active maghemite nanoparticles) was developed (121). Maghemite nanoparticles and method for preparing thereof World Pat. WO/2012/010200). These superparamagnetic nanoparticles were modified with BSAO to improve the uptake, retention and therapeutic efficacy of BSAO. Fluorescent and magnetically drivable adducts comprising of BSAO and iron oxide had a diameter of 10 \pm 2 nm (SAMN@RITC-BSAO). These nanocatalyts are characterized by specific chemical behaviour and combine the advantages of immobilized enzymes with magnetic properties and a fluorescent probe (121) (Fig. 4). The multifunctional nanomaterial has been characterized by transmission electron microscopy (Fig. 5), infrared mass spectrometry and enzyme activity measurements. The immobilized enzyme partially retains its catalytic activity toward polyamine oxidation.

Further investigations showed that bare magnetic nanoparticles form stable colloidal suspension in aqueous solutions. The maximum binding capacity of BSAO was $\sim 6.4 \mathrm{mg} \mathrm{g}^{-1}$ nanoparticles. However, the immobilization procedure reduced the catalytic activity by $\sim 40 \%$, compared to the activity of native enzyme. There was a 2 -fold increase in the Michaelis constant of the enzyme. Taken together, these magnetically drivable nanocatalysts with a fluorescent tag and a specific activity of $0.81 \mathrm{IU} \mathrm{g}^{-1}$ are used in the presence of polyamines for selective killing of tumour cells by the in situ production of $\mathrm{H}_{2} \mathrm{O}_{2}$ and aldehydes (122). 


\section{Conclusions and future perspectives}

Nanotechnology promises major advances in drug delivery, retention and efficacy as well as in diagnostic imaging. Hence these particles are theranostic agents. Gene delivery requires the transport of DNA through the cell membrane. DNA condensation to nanoparticles is a pre-requisite for facile transport of DNA. Oligonucleotide based DNA structures have been designed as drug delivery vehicles. Polyamines are excellent promoters of DNA condensation and investigations into polyamine structure-activity relationship in DNA condensation and transport continues to be an active area of research (123). Numerous studies have demonstrated that $\mathrm{H}_{2} \mathrm{O}_{2}$ and other reactive oxygen species are capable of blocking cells in G1, S or G2 phases of the cell cycle and inhibiting cell growth (124). Utilization of amine oxidase enzymes, especially BSAO can make clinical advances in the future. However, therapeutic applications of radical generating systems are still at the beginning. It is our hope that the utilization of amine oxide activity in the presence of biogenic amines will turn out to be a powerful strategy in the development of new anticancer treatments (73). Since hyperthermia is a clinically established therapeutic method, strategies should be developed that combine hyperthermia with extracellular ROS formation. In support of this idea is the fact that a marked enhancement of cytotoxicity, attributed to $\mathrm{H}_{2} \mathrm{O}_{2}$ and spermine-derived aldehyde(s) has been observed by elevating the temperature of tumour cell cultures from $37^{\circ} \mathrm{C}$ to $42^{\circ} \mathrm{C}(74,88,125)$.

This approach showed a higher sensitivity of MDR human adenocarcinoma and melanoma cells toward cytotoxic spermine metabolites, $\mathrm{H}_{2} \mathrm{O}_{2}$ and aldehydes, compared to the action of these agents on wild-type counterparts of these cells. This finding has been attributed to an early and higher mitochondrial membrane depolarization, and a higher basal production of ROS (82). In fact, $\mathrm{H}_{2} \mathrm{O}_{2}$ could directly interact with some iron of $\mathrm{Fe} / \mathrm{S}$ centres located in the respiratory chain, raising the highly reactive hydroxyl radical (HO') by means of Fenton reaction, which induces oxidation of some thiol $(\mathrm{SH})$ groups, proteins and lipids. Thus, hyperthermia combined with either toxic $\mathrm{BSAO} /$ polyamine metabolites or with thermosensitizing drugs is of great interest to develop a new strategy to overcome MDR of cancer cells. Iron oxide nanoparticles are important theranostic particles since they can be surface modified with reactive groups, antibodies and fluorescent molecules. BSAO immobilization was carried out on PEG and superparamagnetic nanoparticles. Moreover, a recent new strategy showed an increase in the stability of the enzyme and an improvement in releasing cytotoxic products. BSAO was conjugated on a new injectable nanohydrogel $(\mathrm{NH})$, obtained by derivatizing hyaluronic acid (HA) with cholesterol $(\mathrm{CH})$. The high immobilizing capacity of the HA-based anionic NHs with BSAO and retention of the catalytic activity allows the use of the immobilized enzyme BSAO as heterogeneous catalyst of a plug flow microreactor of $\mathrm{H}_{2} \mathrm{O}_{2}$ and aldehyde, inserted into a flow injection analysis system. The HA-based NH complex is a useful controlled delivery system for future therapeutic enzymes application (126). However, all the resulting systems were stable and bioactive, with respect to the free BSAO, indicating how this approach might represent a promising tool in anticancer therapy, for inducing an apoptotic effect on human cancer treatment.

\section{Acknowledgements}

This work was partially supported by Italian MIUR (Ministero dell'Istruzione, dell'Università e della Ricerca) (EA), Fondazione Enrico and Enrica Sovena and by Istituto Pasteur Fondazione Cenci Bolognetti (EA); Foundation of the University of Medicien and Dentistry (Thomas, PC-28-11); Regional Centre of Advanced Technologies and Materials, Palacky University, Olomouc, Czech Republic.

\section{References}

1. Cheng Z, Al Zaki A, Hui JZ, Muzykantov VR and Tsourkas A: Multifunctional nanoparticles: cost versus benefit of adding targeting and imaging capabilities. Science 338: 903-910, 2012.

2. Bertrand N, Wu J, Xu X, Kamaly N and Farokhzad OC: Cancer nanotechnology: the impact of passive and active targeting in the era of modern cancer biology. Adv Drug Deliv Rev 66: 2-25, 2014.

3. Sheridan C: Proof of concept for next-generation nanoparticle drugs in humans. Nat Biotechnol 30: 471-473, 2012.

4. Li H, LaBean TH and Leong KW: Nucleic acid-based nanoengineering: novel structures for biomedical applications. Interface Focus 1: 702-724, 2011.

5. Kawabata A, Baoum A, Ohta N, Jacquez S, Seo GM, Berkland C and Tamura M: Intratracheal administration of a nanoparticlebased therapy with the angiotensin II type 2 receptor gene attenuates lung cancer growth. Cancer Res 72: 2057-2067, 2012.

6. Stahl FW and West SC: Happy Hollidays: 40th anniversary of the Holliday junction. Nat Rev Mol Cell Biol 5: 937-944, 2004.

7. Seeman NC: Nucleic acid junctions and lattices. J Theor Biol 99: 237-247, 1982.

8. Seeman NC: Nanomaterials based on DNA. Annu Rev Biochem 79: $65-87,2010$.

9. Zadegan RM and Norton ML: Structural DNA nanotechnology: from design to applications. Int J Mol Sci 13: 7149-7162, 2012

10. Reishus D, Shaw B, Brun Y, Chelyapov N and Adleman L: Self-assembly of DNA double-double crossover complexes into high-density, doubly connected, planar structures. J Am Chem Soc 127: 17590-17591, 2005.

11. Ke Y, Liu Y, Zhang J and Yan H: A study of DNA tube formation mechanisms using 4-, 8- and 12-helix DNA nanostructures. J Am Chem Soc 128: 4414-4421, 2006.

12. Kuzuya A, Wang R, Sha R and Seeman NC: Six-helix and eighthelix DNA nanotubes assembled from half-tubes. Nano Lett 7: 1757-1763, 2007.

13. He Y, Chen Y, Liu H, Ribbe AE and Mao C: Self-assembly of hexagonal DNA two-dimensional (2D) arrays. J Am Chem Soc 127: 12202-12203, 2005.

14. He Y, Tian Y, Ribbe AE and Mao C: Highly connected twodimensional crystals of DNA six-pointstars. J Am Chem Soc 128: 15978-15979, 2006.

15. Rothemund PW: Folding DNA to create nanoscale shapes and patterns. Nature 440: 297-302, 2006.

16. Endo M, Sugita T, Rajendran A, Katsuda Y, Emura T, Hidaka K and Sugiyama H: Two dimensional DNA origami assemblies using a four-way connector. Chem Commun 47: 3213-3215, 2011.

17. Rajendran A, Endo M, Katsuda Y, Hidaka K and Sugiyama H: Programmed two-dimensional self-assembly of multiple DNA origami jigsaw pieces. ACS Nano 5: 665-671, 2010.

18. Kuzuya A, Kimura M, Numajiri K, Koshi N, Ohnishi T, Okada F and Komiyama M: Precisely programmed and robust 2D streptavidin nanoarrays by using periodical nanometer-scale wells embedded in DNA origami assembly. Chembiochem 10: $1811-1815,2009$

19. Shen W, Zhong H, Neff D and Norton ML: NTA directed protein nanopatterning on DNA Origami nanoconstructs. J Am Chem Soc 131: 6660-6661, 2009. 
20. Hung AM, Micheel CM, Bozano LD, Osterbur LW, Wallraff GM and Cha JN: Large-area spatially ordered arrays of gold nanoparticles directed by lithographically confined DNA origami. Nat Nanotechnol 5: 121-126, 2010.

21. Lund K, Manzo AJ, Dabby N, Michelotti N, Johnson-Buck A, Nangreave J, Taylor S, Pei R, Stojanovic MN, Walter NG, et al: Molecular robots guided by prescriptive landscapes. Nature 465 : 206-210, 2010

22. Gu H, Chao J, Xiao SJ and Seeman NC: A proximity-based programmable DNA nanoscale assembly line. Nature 465 202-205, 2010

23. Wickham SF, Endo M, Katsuda Y, Hidaka K, Bath J, Sugiyama H and Turberfield AJ: Direct observation of stepwise movement of a synthetic molecular transporter. Nat Nanotechnol 6: 166-169, 2011.

24. Endo M, Hidaka K, Kato T, Namba K and Sugiyama H: DNA prism structures constructed by folding of multiple rectangular arms. J Am Chem Soc 131: 15570-15571, 2009.

25. Douglas SM, Dietz H, Liedl T, Hogberg B, Graf F and Shih WM: Self-assembly of DNA into nanoscale three-dimensional shapes. Nature 459: 414-418, 2009.

26. Andersen ES, Dong M, Nielsen MM, Jahn K, Subramani R, Mamdouh W, Golas MM, Sander B, Stark H, Oliveira CL, Pedersen JS, Birkedal V, Besenbacher F, Gothelf KV and Kjems J: Self-assembly of a nanoscale DNA box with a controllable lid. Nature 459: 73-76, 2009.

27. Kuzuya A and Komiyama M: Design and construction of a boxshaped 3D-DNA origami. Chem Commun 28: 4182-4184, 2009.

28. Ke Y, Sharma J, Liu M, Jahn K, Liu Y and Yan H: Scaffolded DNA origami of a DNA tetrahedron molecular container. Nano Lett 9: 2445-2447, 2009.

29. Ke Y, Ong LL, Shih WM and Yin P: Three dimensional structures self-assembled from DNA bricks. Science 338: 1177-1183, 2012.

30. Erben CM, Goodman RP and Turberfield AJ: Single-molecule protein encapsulation in a rigid DNA cage. Angew Chem Int Ed Engl 45: 7414-7417, 2006.

31. Zhao Z, Jacovetty EL, Liu Y and Yan H: Encapsulation of gold nanoparticles in a DNA origami cage. Angew Chem Int Ed Engl 50: 2041-2044, 2011

32. Anderson CJ, Bulte JW, Chen K, Chen X, Khaw BA, Shokeen M, Wooley KL and VanBrocklin HF: Design of targeted cardiovascular molecular imaging probes. J Nucl Med 51 (Suppl 1): $3-17,2010$

33. Douglas SM, Bachelet I and Church GM: A logic-gated nanorobot for targeted transport of molecular payloads. Science 335: 831-834, 2012.

34. Bhatia D1, Chakraborty S, Mehtab S and Krishnan Y: A method to encapsulate molecular cargo within DNA icosahedra. Methods Mol Biol 991: 65-80, 2013

35. Pegg AE: Recent advances in the biochemistry of polyamines in eukaryotes. Biochem J 234: 249-262,1986.

36. Thomas T and Thomas TJ: Polyamines in cell growth and cell death: molecular mechanisms and therapeutic applications. Cell Mol Life Sci 58: 244-258, 2001.

37. Marton LJ and Pegg AE: Polyamines as targets for therapeutic intervention. Annu Rev Pharmacol Toxicol 35: 55-91, 1995.

38. Pignatti C, Tantini B, Stefanelli C and Flamigni F: Signal transduction pathways linking polyamines to apoptosis. Amino Acids 27: 359-365, 2004

39. Seiler N and Raul F: Polyamines and apoptosis. J Cell Mol Med 9: 623-642, 2005.

40. Cohen SS: A Guide to the Polyamines. Oxford University Press, New York, Oxford, 1998.

41. Bachrach U, Wang YC and Tabib A: Polyamines: New cues in cellular signal transduction. News Physiol Sci 16: 106-109, 2001.

42. Childs AC, Mehta DJ and Gerner EW: Polyamine-dependent gene expression. Cell Mol Life Sci 60: 1394-1406, 2003.

43. Thomas $\mathrm{T}$ and Thomas TJ: Regulation of cyclin B1 by estradiol and polyamines in MCF-7 breast cancer cells. Cancer Res 54: $1077-1084,1994$

44. Goldenthal MJ and Marin-Garcia J: Mitochondrial signaling pathways: a receiver/integrator organelle. Mol Cell Biochem 262: $1-16,2004$.

45. Toninello A, Salvi M and Mondovì B: Interaction of biologically active amines with mitochondria and their role in the mitochondrial-mediated pathway of apoptosis. Curr Med Chem 11: 2349-2374, 2004.

46. Thomas TJ and Bloomfield VA: Collapse of DNA caused by trivalent cations: $\mathrm{pH}$ and ionic specificity effects. Biopolymers 22: 1097-1106, 1983
47. Vijayanathan V, Thomas $\mathrm{T}$ and Thomas TJ: DNA nanoparticles and development of DNA delivery vehicles for gene therapy. Biochemistry 41: 14085-14094, 2002.

48. Teif VB and Bohinc K: Condensed DNA: condensing the concepts. Prog Biophys Mol Biol 105: 208-222, 2011.

49. Todd BA, Parsegian VA, Shirahata A, Thomas TJ and Rau DC: Attractive forces between cation condensed DNA double helices. Biophys J 94: 4775-4782, 2008.

50. Carlstedt J, Lundberg D, Dias RS and Lindman B: Condensation and decondensation of DNA by cationic surfactant, spermine, or cationic surfactant-cyclodextrin mixtures: macroscopic phase behaviour, aggregate properties, and dissolution mechanisms. Langmuir 28: 7976-7989, 2012.

51. Saminathan M, Antony T, Shirahata A, Sigal LH, Thomas T and Thomas TJ: Ionic and structural specificity effects of natural and synthetic polyamines on the aggregation and resolubilization of single, double, and triple-starnded DNA. Biochemistry 38: 3821-3830, 1999

52. Saraf A, Hacker MC, Sitharaman B, Grande-Allen KJ, Barry MA and Mikos AG: Synthesis and conformational evaluation of a novel gene delivery vector for human mesenchymal stem cells. Biomacromolecules 9: 818-827, 2008.

53. Nayvelt I, Thomas T and Thomas TJ: Mechanistic differences in DNA nanoparticle formation in the presence of oligolysines and poly-L-lysine. Biomacromolecules 8: 477-484, 2007.

54. Vijayanathan V, Thomas T, Shirahata A and Thomas TJ: DNA condensation by polyamines: a laser light scattering study of structural effects. Biochemistry 40: 13644-13651, 2001

55. Thomas RM, Thomas T, Wada M, Sigal LH, Shirahata A and Thomas TJ: Facilitation of the cellular uptake of a triplex forming oligonucleotide by polyamine analogues: structure-activity relationships. Biochemistry 38: 13328-13337, 1999.

56. Seiler N: Polyamine catabolism and elimination by the vertebrate organism. In: Polyamines in the Gastrointestinal Tract. Dowling RH, Fölsch UR and Löser G (eds). Kluwer Academic Publishers, Dordrecht, pp65-85, 1992.

57. Agostinelli E, Arancia G, Dalla Vedova L, Belli F, Marra M, Salvi $\mathrm{M}$ and Toninello A: The biological functions of polyamine oxidation products by amine oxidases: perspectives of clinical applications. Amino Acids 27: 347-358, 2004.

58. Mondovì B, Riccio P, Agostinelli E and Marcozzi G: Oxidation of diamines and polyamines. In: The Physiology of Polyamines. Bachrach U and Heimer YM (eds). Vol. 1. CRC Press, Boca Raton, FL, pp177-201, 1989.

59. Binda C, Mattevi A and Edmondson DL: Structure-function relationships in flavoenzyme-dependent amine oxidations. J Biol Chem 277: 23973-23976, 2002.

60. Janes SM, Mu D, Wemmer D, Smith AJ, Kaur S, Maltby D, Burlingame AL and Klinman JP: A new redox cofactor in eukaryotic enzymes: 6-hydroxydopa at the active site of bovine serum amine oxidase. Science 248: 981-987, 1990.

61. Edmondson DL, Binda C and Mattevi A: Structural insights into the mechanism of amine oxidation by monoamine oxidase $\mathrm{A}$ and B. Arch Biochem Biophis 464: 269-276, 2007.

62. Edmondson DL, Binda C, Wang J, Upadhyay AK and Mattevi A: Molecular and mechanistic properties of the membranebound mitochondrial monoamine oxidases. Biochemistry 48: 4220-4230, 2009.

63. Agostinelli E, Tempera G, Molinari A, Salvi M, Battaglia V, Toninello A and Arancia G: The phisiological role of biogenic amines redox reactions in mitochondria. New perspective in cancer therapy. Amino Acids 33: 175-187, 2007.

64. Agostinelli E, Tempera G, Tandurella E, Pintus F, Spanò D, Medda R and Floris G: The role of copper amine oxidases in the metabolism of polyamine and their therapeutic implications. In: Biological Aspects of Biogenic Amines, Polyamines and Conjugates. Dandrifosse G (ed). ISBN: 978-81-7895-249-9. Transworld Research Network, 2009.

65. Floris G and Mondovì B: Copper Amine Oxidases. CRC Press, Boca Ranton, FL, 2009.

66. Wang Y, Devereux W, Woster PM, Stewart TM, Hacker A and Casero RA Jr : Cloning and characterization of human polyamine oxidase that is inducible by polyamine analogue exposure. Cancer Res 61: 5370-5373, 2001.

67. Vujcic S, Diegelman P, Bacchi CJ, Kramer DL and Porter CW: Identification and characterization of a novel flavin containing spermine oxidase of mammalian cell origin. Biochem J 367: 665-675, 2002.

68. Casero RA Jr and Marton LJ: Targeting polyamine metabolism and function in cancer and other hyperproliferative diseases. Nat Rev Drug Discov 6: 373-390, 2007. 
69. Babbar $\mathrm{N}$ and Casero RA Jr: Tumor necrosis factor $\alpha$ increases reactive oxygen species by inducing spermine oxidase in human lung epithelial cells: a potential mechanism for inflammation induced carcinogenesis. Cancer Res 66: 11125-11130, 2006.

70. Casero RA Jr and Pegg A: Polyamine catabolism and disease. Biochem J 421: 323-338, 2009.

71. Seiler N: Thirty years of polyamine-related approaches to cancer therapy. Retrospect and prospect. Part 1. Selective enzyme inhibitors. Curr Drug Targets 4: 537-564, 2003.

72. Seiler N: Thirty years of polyamine-related approaches to cancer therapy. Retrospect and prospect. Part 2. Structural analogues and derivatives. Curr Drug Targets 4: 565-585, 2003.

73. Averill-Bates DA, Cherif A, Agostinelli E, Tanel A and Fortier G Anti-tumoral effect of native and immobilized bovine serum amine oxidase in a mouse melanoma model. Biochem Pharmacol 69: 1693-1704, 2005.

74. Agostinelli E, Belli F, Molinari A, Condello M, Palmigiani P Vedova LD, Marra M, Seiler N and Arancia G: Toxicity of enzymatic oxidation products of spermine to human melanoma cells (M14): sensitisation by heat and MDL 72527. Biochim Biophys Acta 1763: 1040-1050, 2006.

75. Agostinelli E, Dalla Vedova L, Belli F, Condello M, Arancia G and Seiler N: Sensitization of human colon adenocarcinoma cells $(\mathrm{LoVo})$ to reactive oxygen species by a lysosomotropic compound. Int J Oncol 29: 947-955, 2006.

76. Henle KJ, Moss AJ and Nagle WA: Mechanism of spermidine cytotoxicity at 37 degrees $\mathrm{C}$ and 43 degrees $\mathrm{C}$ in Chinese hamster ovary cells. Cancer Res 46: 175-182, 1986.

77. Bachrach U, Ash I, Abu-Elheiga L, Hershkovitz M and Loyter A: Fusion-mediated microinjection of active amine and diamine oxidases into cultured cells: effect on protein and DNA synthesis in chick embryo fibroblasts and in glioma cells. J Cell Physio 131: 92-98, 1987

78. Heby $\mathrm{O}$ and Persson L: Molecular genetics of polyamine synthesis in eukaryotic cells. Trends Biochem Sci 15: 153-158, 1990.

79. Calcabrini A, Arancia G, Marra M, Crateri P, Befani O, Martone A and Agostinelli E: Enzymatic oxidation products of spermine induce greater cytotoxic effects on human multidrugresistant colon carcinoma cells (LoVo) than on their wild type counterparts. Int J Cancer 99: 43-52, 2002.

80. Lindsay GS and Wallace HM: Changes in polyamine catabolism in HL-60 human promyelogenous leukaemic cells in response to etoposide-induced apoptosis. Biochem J 337: 83-87, 1999.

81. Toninello A, Pietrangeli P, De Marchi U, Salvi M and Mondovi B Amine oxidases in apoptosis and cancer. Biochim Biophys Acta 1765: 1-13, 2006.

82. Arancia G, Calcabrini A, Marra M, Crateri P, Artico M, Martone A, Martelli F and Agostinelli E: Mitochondrial alterations induced by serum amine oxidase and spermine on human multidrug resistant tumor cells. Amino Acids 26 : 273-282, 2004

83. Kumar CS and Mohammad F: Magnetic nanomaterials for hyperthermia-based therapy and controlled drug delivery. Adv Drug Deliv Rev 63: 789-808, 2011.

84. Vernon CC, Hand JW, Field SB, Machin D, Whaley JB, Van der Zee J, Van Putten WL, Van Rhoon GC, Van Dijk JD, Gonzalez D, Liu FF, Goodman P and Sherar M: Radiotherapy with or without hyperthermia in the treatment of superficial localized breast cancer: results from five randomized controlled trials. International Collaborative Hyperthermia Group. Int J Radiat Oncol Biol Phys 35: 731-744, 1996.

85. Amendola R, Cervelli M, Fratini E, Sallustio DE, Tempera G, Ueshima T, Mariottini P and Agostinelli E: Reactive oxygen species spermine metabolites generated from amine oxidases and radiation represent a therapeutic gain in cancer treatments. Int J Oncol 43: 813-820, 2013.

86. Amendola R, Cervelli M, Tempera G, Fratini E, Varesio L, Mariottini P and Agostinelli E: Spermine metabolism and radiation-derived reactive oxygen species for future therapeutic implications in cancer: an additive or adaptive response. Amino Acids 46: 487-498, 2014.

87. Niemirowicz K, Markiewicz KH, Wilczewska AZ and Car H: Magnetic nanoparticles as new diagnostic tools in medicine. Adv Med Sci 57: 1-12, 2012.

88. Agostinelli E, Belli F, Dalla Vedova L, Marra M, Crateri P and Arancia G: Hyperthermia enhances cytotoxicity of amine oxidase and spermine on drug-resistant LoVo colon adenocarcinoma cells. Int J Oncol 28: 1543-1553, 2006
89. Averill-Bates DA, Agostinelli E, Przybytkowski E and Mondovi B: Aldehyde dehydrogenase and cytotoxicity of purified bovine serum amine oxidase and spermine in Chinese hamster ovary cells. Biochem Cell Biol 72: 36-42, 1994.

90. Yoshikawa T, Kokura S, Tainaka K, Naito Y and Kondo M: A novel cancer therapy based on oxygen radicals. Cancer Res 55: $1617-1620,1995$

91. Hahn GM: Hyperthermia and Cancer. Plenum Press, New York, 1982.

92. Gerner EW, Holmes DK, Stickney DG, Noterman JA and Fuller DJ: Enhancement of hyperthermia-induced cytotoxicity by polyamines. Cancer Res 40: 432-438, 1980 .

93. Nagele A, Meier T and Issels RD: Thermosensitization, depletion of glutathione, and modulation of polyamine catabolism in $\mathrm{CHO}$ cells by the aminothiol WR-1065. Prog Pharm Clin Pharm 8: 176-180, 1990.

94. Kapp DS and Hahn GM: Thermosensitization by sulfhydryl compounds of exponentially growing Chinese hamster cells. Cancer Res 39: 4630-4635, 1979.

95. Averill-Bates DA, Agostinelli E,Przybytkowski E, Mateescu MA and Mondovì B: Cytotoxicity and kinetic analysis of purified bovine serum amine oxidase in the presence of spermine in Chinese hamster ovary cells. Arch Biochem Biophys 300: 75-79, 1993.

96. AgostinelliE,PrzybytkowskiE,Mondovì B and Averill-Bates DA: Heat enhancement of cytotoxicity induced by oxidation product of spermine in Chinese hamster ovary cells. Biochem Pharmacol 48: 1181-1186, 1994.

97. Demers N, Agostinelli E, Averill-Bates DA and Fortier G: Immobilization of native and polyethyleneglycol-treated ('PEGylated') bovine serum amine oxidase into a biocompatible hydrogel. Biotechnol Appl Biochem 33: 201-207, 2001.

98. Agostinelli E and Seiler N: Non-irradiation-derived reactive oxygen species (ROS) and cancer: therapeutic implications. Amino Acids 31: 341-355, 2006.

99. Agostinelli E, Riccio B, Mucigrosso J, Befani O and Mondovì B: On the handling of amine oxidase activity as a biochemical tool: perspectives. In: Perspectives in Polyamine Research. Perin A, Scalabrino G, Sessa A and Ferioli ME (eds). Wichtig Editor, Milan, pp17-19, 1988.

100. Dini L, Agostinelli E and Mondovì B: Cultured epatocytes bind and internalize bovine serum amine oxidase-gold complexes. Biochem Biophys Res Commun 179: 1169-1174, 1991.

101. Ansari SA and Husain Q: Potential applications of enzymes immobilized on/in nano materials: A review. Biotechnol Adv 30: 512-523, 2012

102. Sasaki Y, Usuki N, Matsuo K and Kishimoto M: Development of NanoCAP technology for high-density recording. IEEE Trans Magn 41: 3241-3243, 2005.

103. Fouda MFR, El-Kholy MB, Moustafa SA, Hussien AI, Wahba MA and El-Shahat MF: Synthesis and characterization of nanosized $\mathrm{Fe}_{2} \mathrm{O}_{3}$ pigments. Int J Inorg Chem 2012: 1-9, 2012.

104. Magro M, Baratella D, Salviulo G, Polakova K, Zoppellaro G, Tucek J, Kaslik J, Zboril R and Vianello F: Core-shell hybrid nanomaterial based on prussian blue and surface active maghemite nanoparticles as stable electrocatalyst. Biosens Bioelectron 52 159-165, 2014.

105. Baratella D, Magro M, Sinigaglia G, Zboril R, Salviulo G and Vianello F: A glucose biosensor based on surface active maghemite nanoparticles. Biosens Bioelectron 45: 13-18, 2013.

106. Magro M, Baratella D, Pianca N, Toninello A, Grancara S, Zboril R and Vianello F: Electrochemical determination of hydrogen peroxide production by isolated mitochondria: a novel nanocomposite carbon-maghemite nanoparticle electrode. Sens Actuators B Chem 176: 315-322, 2013.

107. Magro M, Faralli A, Baratella D, Bertipaglia I, Giannetti S, Salviulo G, Zboril R and Vianello F: Avidin functionalized maghemite nanoparticles and their application for recombinant human biotinyl-SERCA purification. Langmuir 28: 15392-15401, 2012.

108. Tassa C, Shaw SY and Weissleder R: Dextran-coated iron oxide nanoparticles: a versatile platform for targeted molecular imaging, molecular diagnostics, and therapy. Acc Chem Res 44: 842-852, 2011

109. Saito S, Tsugeno M, Koto D, Mori Y, Yoshioka Y, Nohara S and Murase K: Impact of surface coating and particle size on the uptake of small and ultrasmall superparamagnetic iron oxide nanoparticles by macrophages. Int J Nanomed 7: 5415-5421, 2012 . 
110. Wang J, Huang Y, David AE, Chertok B, Zhang L, Yu F and Yang VC: Magnetic nanoparticles for MRI of brain tumors. Curr Pharm Biotechnol 13: 2403-2416, 2012.

111. Skopalik J,Polakova K, Havrdova M, Justan I, Magro M, Milde D, Knopfova L, Smarda J, Polakova H, Gabrielova E, Vianello F, Michalek J and Zboril R: Mesenchymal stromal cell labeling by new uncoated superparamagnetic maghemite nanoparticles in comparison with commercial Resovist - an initial in vitro study. Int J Nanomed 2014. http://dx.doi.org/10.2147/IJN.S66986.

112. Kanwar JR, Roy K and Kanwar RK: Chimeric aptamers in cancer cell-targeted drug delivery. Crit Rev Biochem Mol Biol 46: 459-477, 2011.

113. Kubinova S and Sykova E: Nanotechnologies in regenerative medicine. Minim Invasive Ther Allied Technol 19: 144-156, 2010

114. Kiessling F, Huppert J, Zhang C, Jayapaul J, Zwick S, Woenne EC, Mueller MM, Zentgraf $\mathrm{H}$, Eisenhut M, Addadi Y, Neeman M and Semmler W: RGD-labeled USPIO inhibits adhesion and endocytotic activity of alpha $\mathrm{v}$ beta3-integrinexpressing glioma cells and only accumulates in the vascular tumor compartment. Radiology 253: 462-469, 2009.

115. Dias AM, Hussain A, Marcos AS and Roque AC: A biotechnological perspective on the application of iron oxide magnetic colloids modified with polysaccharides. Biotechnol Adv 29: $142-155,2011$

116. Hilger I and Kaiser WA: Iron oxide-based nanostructures for MRI and magnetic hyperthermia. Nanomedicine 7: 1443-1459, 2012.

117. Lin MM, Kim HH, Kim H, Dobson J and Kim do K: Surface activation and targeting strategies of superparamagnetic iron oxide nanoparticles in cancer-oriented diagnosis and therapy. Nanomedicine 5: 109-133, 2010.

118. Devi GR: siRNA-based approaches in cancer therapy. Cancer Gene Ther 13: 819-829, 2006.
119. Taratula O, Garbuzenko O, Savla R, Wang YA, He H and Minko T: Multifunctional nanomedicine platform for cancer specific delivery of siRNA by superparamagnetic iron oxide nanoparticles-dendrimer complexes. Curr Drug Deliv 8: 59-69, 2011.

120. Jabir NR, Tabrez S, Ashraf GM, Shakil S, Damanhouri GA and Kamal MA: Nanotechnology-based approaches in anticancer research. Int J Nanomed 7: 4391-4408, 2012.

121. Magro M, Valle G, Russo U, Nodari L and Vianello F: Maghemite nanoparticles and method for preparing thereof. International Patent Application WO/2012/010200, 2012.

122. Sinigaglia G, Magro M, Miotto G, Cardillo S, Agostinelli E, Zboril R, Bidollari E and Vianello F: Catalytically active bovine serum amine oxidase bound to fluorescent and magnetically drivable nanoparticles. Int J Nanomed 7: 2249-2259, 2012.

123. Vijayanathan V, Agostinelli E, Thomas T and Thomas TJ: Innovative approaches to the use of polyamines for DNA nanoparticle preparation for gene therapy. Amino Acids 46: 499-509, 2014

124. Boonstra J and Post JA: Molecular events associated with reactive oxygen species and cell cycle progression in mammalian cells. Gene 337: 1-13, 2004.

125. Agostinelli E, Condello M, Molinari A, Tempera G, Viceconte N and Arancia G: Cytotoxicity of spermine oxidation products to multidrug resistant melanoma M14 ADR2 cells: Sensitization by the MDL 72527 lysosomotropic compound. Int J Oncol 35: 485-498, 2009.

126. Montanari E, Capece S, Di Meo C, Meringolo M, Coviello T, Agostinelli E and Matricardi P: Hyaluronic acid nanohydrogels as a useful tool for BSAO immobilization in the treatment of melanoma cancer cells. Macromol Biosci 13: 1185-1194, 2013. 